\title{
Assay of population density of amylase producing bacteria from different soil samples contaminated with flowing effluents
}

\author{
Bahadure R.B., Agnihotri U.S. and Akarte S.R. \\ Department of Zoology, Vidya Bharati Mahavidyalaya Amravati.444 602, rgene1@yahoo.co.in \& \\ srakarte@rediffmail.com
}

\begin{abstract}
Industrial microbiology deals with soil terms with life, from the distinct viruses to larger bacteria, fungi, algae and protozoa, up to macroscopic worms and insects. Many microorganisms that live in the soil play indispensable role in maintaining life of this planet degrading or chemically modifying molecules. Considerable human interest in soil organisms stems from their ability to synthesize a variety of useful chemicals. Environmental conditions affect the density and composition of the flora of the soil.

Academic observation can yield practical possibilities and industrial fermentation industries often keep close watch on theoretical studies being carried out in laboratories. Industrial microbiology concern itself with the isolation and description of microorganism from natural environments, such as soil or water. The population density of microorganisms based on their survival and their enzyme producing activity can be primarily screened along with its propagation activity. Considering this soil sample from different stations were collected to observe the amylase producing activity of bacterial population and thereby further identifying different types of such bacteria in effluent contaminated soil and water.
\end{abstract}

\section{Introduction}

The early detection of small percentage of useful microorganisms that are presence in the soil and water can be screened primarily for detection and isolation of only those microorganisms which are of interest from among the large microbial population. Many successful industrial fermentation processes heavily depend on enzymes from microorganisms. Amylases are produced by variety of living organisms, ranging from bacteria to plants and humans. Bacteria and fungi secret amylases to the outside for their cells to carry out extra cellular digestion. These amylases are employed commercially for preparation of sizing agents and removal of starch sizing from woven cloth, preparation of starch sizing plate's liquefaction of heavy starch pastes formed during heating steps in the manufacture of corn and chocolate, syrups, production of breads, in brewing industry. These Bacteria are screened from natural resources, for its ability to grow on cheap substrates, producing enzymes at high stable rate, no toxic substances. So for study of the population density of amylase producing bacteria, a survey of soil samples near by flowing effluents was done.

\section{Materials and Method}

Collection of Samples:

Soil samples were collected from different spots along the bank of flowing effluent through local stream of water for the study of enzyme producing microorganisms. The locations selected were from and around the Amravati city and other places away from the Amravati city where the flowing water is discharged outside the city.

Preparation of culture media for Microorganisms: A culture media of Agar solution with Carbon sources and Salt solution-prepared kept in Autoclave and then inoculated on pouring plates.
Preparation of Soil extract:

After collecting the soil samples from various localities in the Amravati City.

$\rightarrow \quad 0.1 \mathrm{gm}$. of soil sample $+10 \mathrm{ml}$. of doubled D/W.

$\rightarrow \quad$ Mix thoroughly by vortexer and incubate it for $30 \mathrm{~min}$. at $37^{\circ} \mathrm{C}$ in incubator.

$\rightarrow \quad$ Allow it to settle, and use $0.2 \mathrm{ml}$. of the supernatant for plating directly for serial dilution use sterile doubled D/W, and dilute as shown bellow.

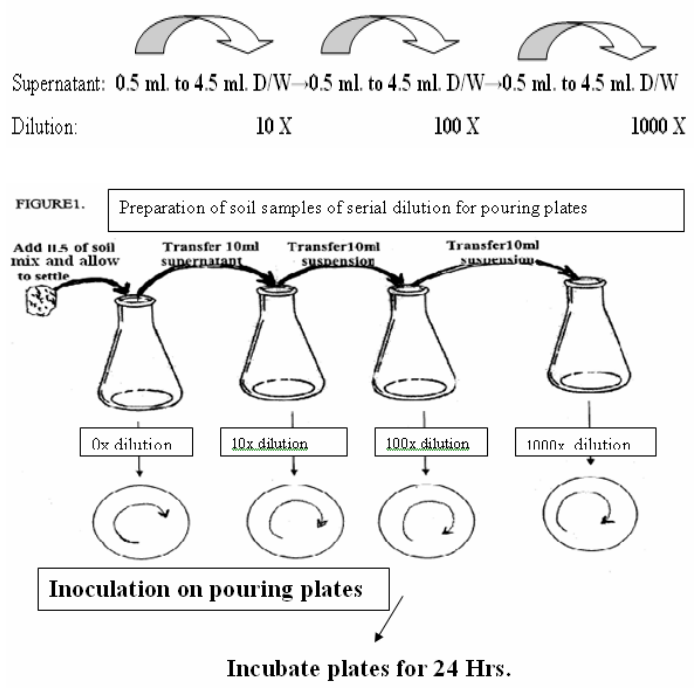

For Inoculation $0.2 \mathrm{ml}$ of each dilution on Carbon source of plates. Incubate at $37^{\circ} \mathrm{C}$ for 1 to 2 days. Count the number of colonies in each plate of dilutions.

Staining of plates for Amylase producing Bacteria:

lodine / Potassium lodide:-

$0.2 \% \mathrm{I}_{2}$ in $2 \% \mathrm{KI}$ in doubled $\mathrm{D} / \mathrm{W}$ (leave it on a shaker to dissolve iodine). After $24 \mathrm{hrs}$. of growth 
the starch plates are flooded with the above iodine solution cleared zones are seen around amylase producing colonies under blue background.

\section{Discussion and Conclusion}

So it is far necessary to screening the soil and water bacteria for their amylase, cellulase production which could be a major source of enzyme after pure culture on large scale. The productions of enzymes for cost effectiveness can be processed by chemicals and antibiotics adopt three different strategies are as fallows.

i) Proper selection of strain.

ii) Improvement of strain for mutates the existing strain.

iii) Modification of strain for molecular cloning of genes for overproduction of enzymes.

The most attention is paid forwards an enzyme producing bacteria in recent years because of their great potential for microbiological and Biotechnological exploitation on the basis of following criteria

\# Screening for microorganisms in soil for starch degrading enzymes.

\# Screening for organic acids.

\# Screening for antibiotics.

\# Production of antibiotics against specific microorganisms.

\# Screening for lipase producing microorganisms. \# Production of cellulase degrading enzymes.

The preliminary screening of environmental bacterial has prime importance as the soil and water are the major sources for varieties of bacteria as well as their enzyme producing activity. The first starch-degrading enzyme alkaline amylase was produced in Horikoshi-II medium by cultivating alkaliphilic Bacillus species. Strain A-40-2(Horikoshi, 1971). The second report of alkaline amylase producing three alkaliphilic Bacillus strain reported by McTigue et al. 1994. Kimura and Horikoshi et al. 1990 , isolated at number of starch-degrading psychrotrophic microorganisms from the environment. Two highly alkaliphilic pullulanase producing bacteria were isolated from Korean soil (Kim et al. 1953). Matsuzawa et al. 1975, estiblished the industrial production of cyclodextrin (CD), by using crude of Cyclomaltodextrin Glycosyltransferase (CGTase) which is bacterial Origin produce cyclodextrin. Georganta et al. 1993 isolated CGTase producing Psychrophilic alkaliphilic bacteria from samples of deep-sea bottom mud.

\section{References}

[1] Georganta G., Kaneko T., Kudo T. and Horikoshi K. (1993) Starch 45:95-99.

[2] Horikoshi K.(1971) Agric.Biol.Chem. 35:1783-1791.

[3] MatsuzawaM.,.Kawano M., Nakmura N. and Horikoshi K. (1975) Starch 27:410-413.

[4] McTigue M. A., Kelly C.T., Fogarty W.M. and Doyle E.M. (1994) Biotecnol. Lett. 16:569-574. 


\section{Observations and Results}

\begin{tabular}{|l|l|l|r|r|r|r|}
\hline Sample No. & $\begin{array}{l}\text { Selection } \\
\text { Plate }\end{array}$ & \multicolumn{4}{l|}{$\begin{array}{l}\text { Volume } \\
(\mathrm{ml})\end{array}$} & \multicolumn{4}{|l|}{ Dilution Number of colony counted } \\
\hline & & & \multicolumn{1}{l|}{ lx } & \multicolumn{1}{l|}{$10 \mathrm{x}$} & \multicolumn{1}{l|}{$100 \mathrm{x}$} & $1000 \mathrm{x}$ \\
\hline 1. Chattri Lake & Soil plate & $200(\mathrm{ml})$ & 187 & 56 & 50 & 30 \\
\hline 2. Pedhi River & Soil plate & $200(\mathrm{ml})$ & 221 & 152 & 98 & 44 \\
\hline 3. Chudaman River & Soil plate & $200(\mathrm{ml})$ & 155 & 133 & 102 & 91 \\
\hline & & & & & & \\
\hline 4. College (Botanical Garden). & Soil plate & $200(\mathrm{ml})$ & 110 & 55 & 33 & 25 \\
\hline $\begin{array}{l}\text { 5. Ambanala Origin (Wadli } \\
\text { Lake). }\end{array}$ & Soil plate & $200(\mathrm{ml})$ & 202 & 192 & 180 & 167 \\
\hline 6. Ambanala Ending. & Soil plate & $200(\mathrm{ml})$ & 314 & 283 & 262 & 187 \\
\hline 7. Industrial Effluent Origin. & Soil plate & $200(\mathrm{ml})$ & 290 & 269 & 241 & 224 \\
\hline 8. Industrial Effluent Ending. & Soil plate & $200(\mathrm{ml})$ & 357 & 320 & 246 & 170 \\
\hline
\end{tabular}


Staining the plates for Amylase producing Bacteria:(Soil Samples)

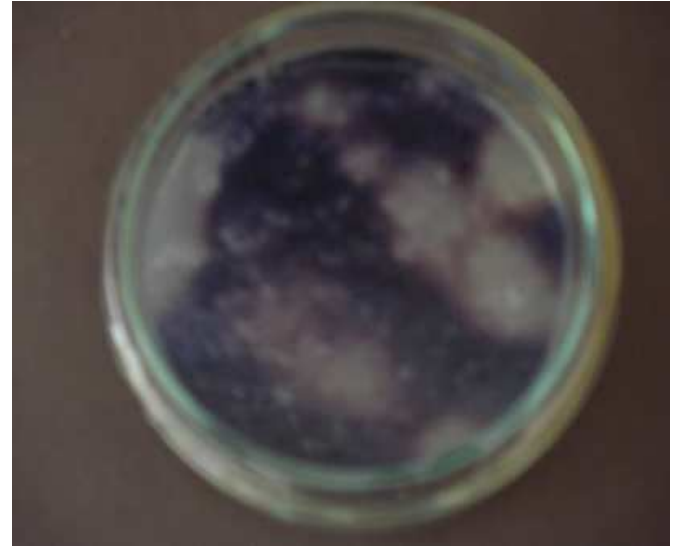

Chatri Lake (1000 XDilution)

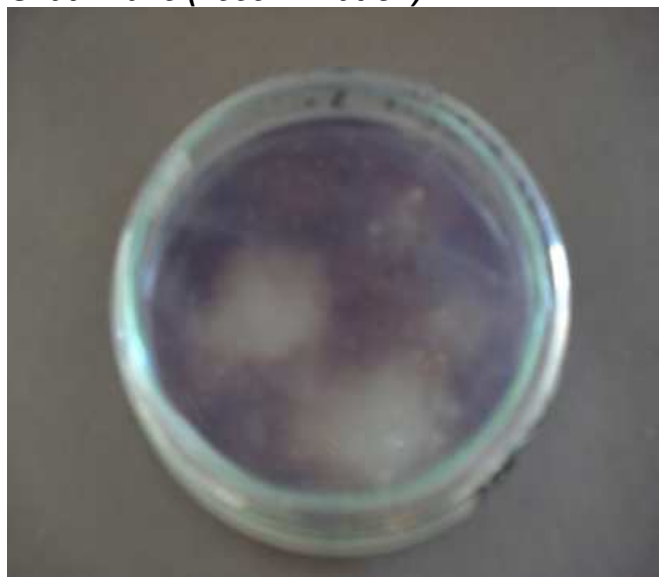

Chudaman River (1000 X Dilution)

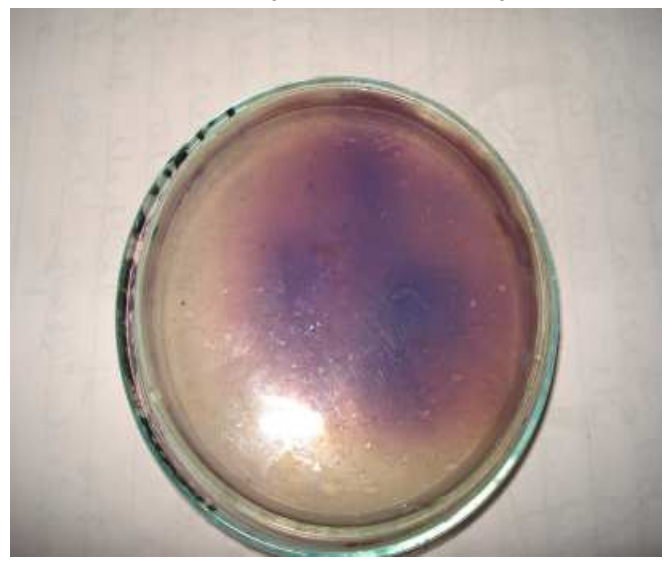

Ambanala Origin (1000 X Dilution)

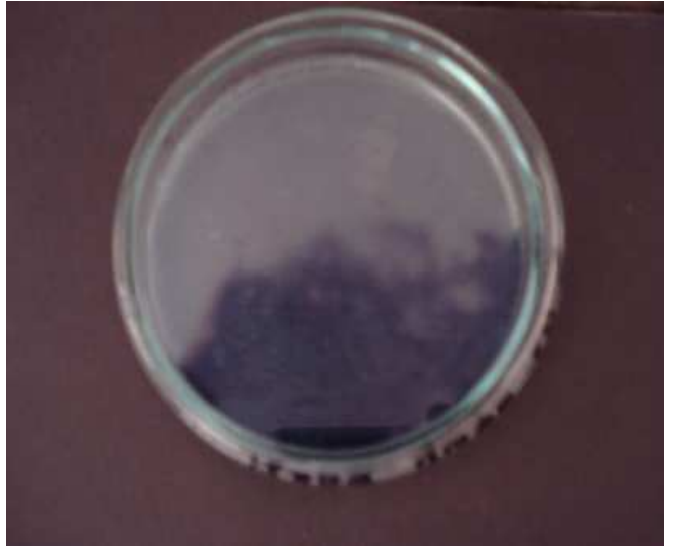

Pedhi River (1000 X Dilution)

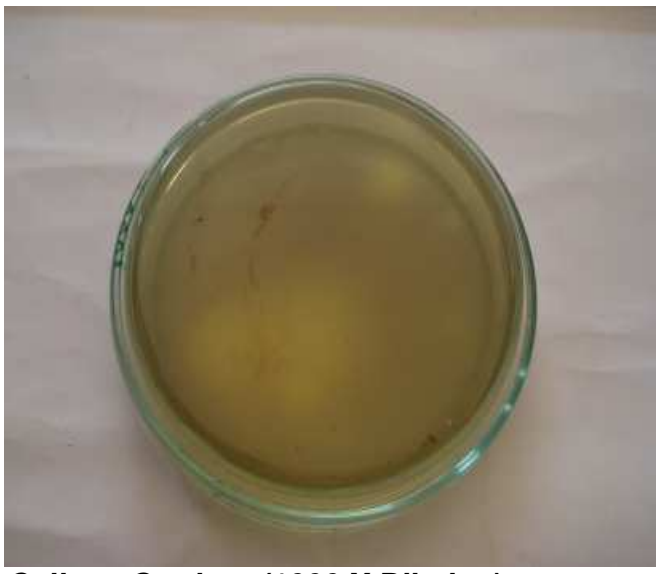

College Gardern (1000 X Dilution)

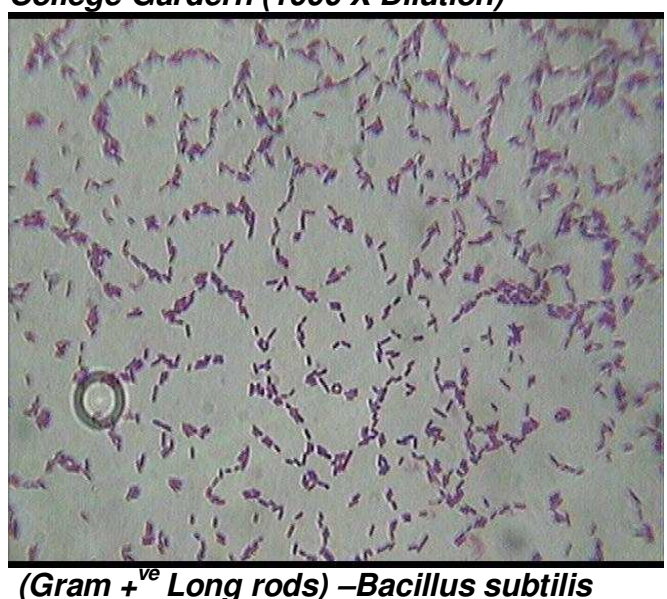




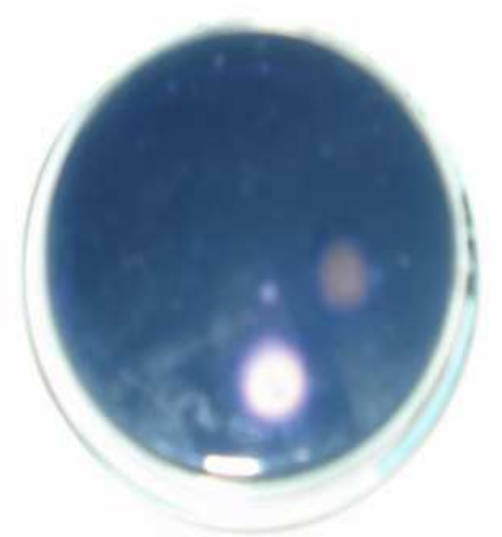

Ambanala Ending (1000 X Dilution)

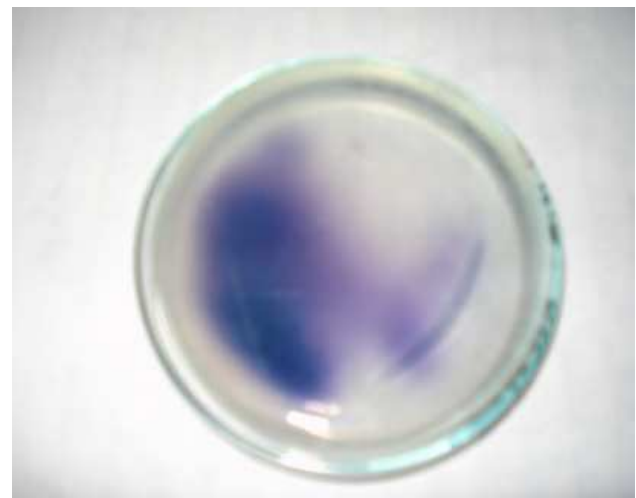

Industrial Origin (1000X Dilution)

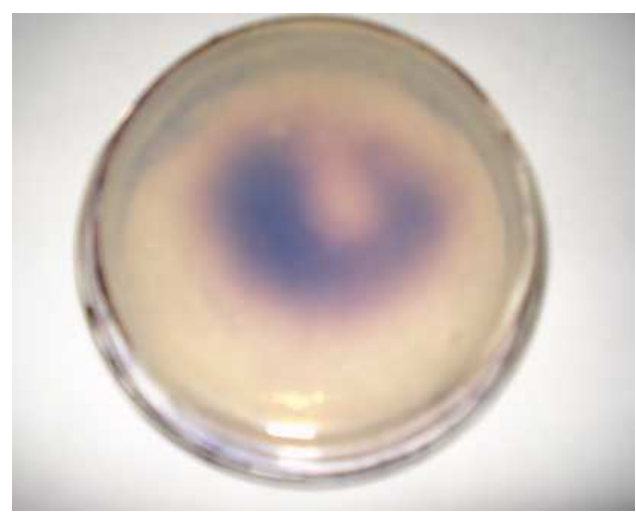

Industrial Ending (1000 X Dilution)
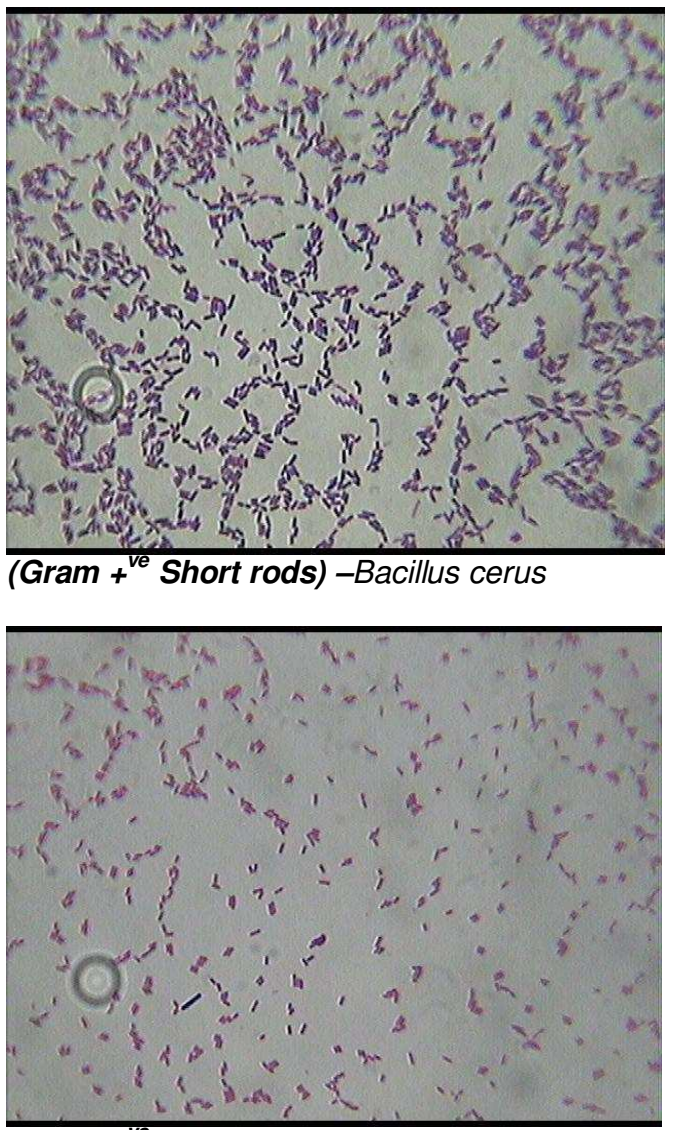

(Gram + ${ }^{\text {ve }}$ Short rods)-Bacillus cerus

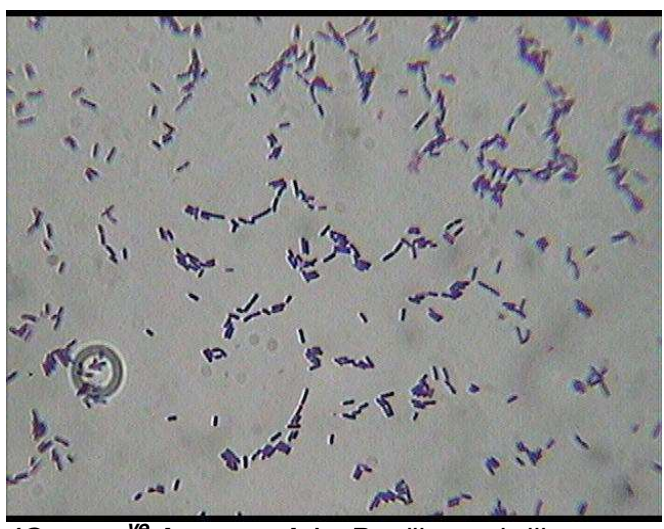

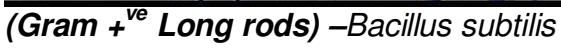

